\title{
Effect of herbicides on photosynthetic electron transport and on the growth of the alga Scenedesmus quadricauda
}

W. HENDRICH*, Z. KUBIAK *, K, JURAJDA **, M. PAWLACZYK-SZPILOWA ***

* Institute of Biochemistry, Wrocław University; ** Institute of Botany, Wrocław University; *** Institute of Environment Protection Engineering, Technical University, Wrocław

(Received: June 10, 1975)

\section{Abstract}

The inhibitory effect of herbicides on the Hill reaction (with 2,6-dichlorophenol-indophenol as acceptor) and their influence on development of the alga Scenedesmus quadricauda was studied. The following herbicides were tested: 2,4-D, Gramoxone, Afalon, Kresamone, CIPC and Simazine. The results are discussed in terms of the mechanism of action of the investigated herbicides.

\section{INTRODUCTION}

The mechanism of action of herbicides is not completely elucidated. Investigations on the uptake of these substances from the environment, on their metabolism and the toxity of herbicides and their metabolites (Kearney and Kaufman, 1971, Mashtakov, Dieyeva and Volyniets, 1971; Mielnikov, Baskakov and Bokariev, 1956; Moreland, 1967) have thrown light in some cases on the mechanism of action of herbicides and also on the important phenomenon of selective toxicity to various plant organisms.

From among various herbicides a group of photosynthesis inhibitors may be singled out which affect the photosynthetic activity of plants. Here belong phenylurea derivatives, acylanilides, N-substituted urethanes and triazines. However, even as regards these compounds acting on basal processes in plants, a certain selectivity of their toxicity is observed. For instance the resistivity of maize (Zea Mays) to the action of Simazin* is attributed to the ability of this plant to rapidly metabolize this compound

* Abbreviations and notations used in text: 2,4-D - 2,4-dichlorophenoxyacetic acid; Afalon: N-(3,4-dichlorophenyl)-N'methoxy-N'-methylurea; CIPC — isopropyl ester of 3-chlorocarbanilic acid; chl. - chlorophyll; DCPIP - 2,6-dichlorophenol-indophenol; CMU - N-(4-chlorophenyl)-N'-dimethylurea; DCMU - N-(3,4-dichlorophenyl)-N'dimethylurea; Gramoxone-paraquat, 1,1'-dimethyl-4,4'-dipyridylchloride; IAA - 3-indolylacetic acid; Kresamone - DNOC, 2,4-dinitro-ortho-cresol; Simazine - 2-chloro-4,6-diethylamimo-sym-triazin. 
to the nontoxic 2-hydroxy derivative ( $\mathrm{H}$ a milto $\mathrm{n}$ and $\mathrm{M}$ oreland, 1962). The herbicides CMU and DCMU inhibit electron transport in the photosynthetic apparatus. This transport is inhibited in 50 per cent in algae at a herbicide concentration 5 times that used for isolated chloroplasts (I z awa and Good, 1965).

Much wider differences in toxicity are observed in the case of herbicides of other types. 2,4-D for instance exerts a protective influence on IAA in monocotyledonous plants ( $\mathrm{H}$ e n d e rs on, Mille r and D e s se, 1954), whereas it stimulates IAA breakdown in dicotyledones (L o ck$\mathrm{h}$ art and Weintraub, 1957). The effect on the Hill reaction (experiments on isolated maize chloroplasts with DCPIP as acceptor) depends on the 2,4-D concentration: at low concentrations $(14.2 \mu \mathrm{g} / 3 \mathrm{ml})$ stimulation was observed, whereas high concentration $(142 \mu \mathrm{g} / 3 \mathrm{ml})$ inhibited the reaction (Mashtakov, Dieyeva and Volyniets, 1971).

Most research work on the action of herbicides was performed on higher plants (Mor eland, 1967). The present paper reports the results of investigation on the effect of some herbicides on the alga Scenedesmus quadricauda. This species was chosen in view of its common occurrence in natural environments, and the studies may be of practical importance for environment protection. The available literature data indicate that these organisms are a material difficult to handle in biochemical investigations. Tetik (1969) describes that comminution of algae in a bead mill gives as a result fragmented chloroplasts. Gra ha m and $\mathrm{Smillie}$ (1971) studied the photosynthetic activity of preparations obtained from Scenedesmus obliquus. The latter showed a low activity in the Hill reaction $\left(49-61 \mu\right.$ moles DCPIP. $\mathrm{mg}^{-1} \mathrm{ch} / \mathrm{h}^{-1}$ and $154-182 \mu \mathrm{moles}$ $\mathrm{K}_{3} \mathrm{Fe}(\mathrm{CN})_{6} \cdot \mathrm{mg}^{-1} \mathrm{chl} / \mathrm{h}^{-1}$ and 52 moles $\left.\mathrm{NADP} \cdot \mathrm{mg}^{-1} \mathrm{chl} / \mathrm{h}^{-1}\right)$, a very low cyclic phosphorylation activity (8-15 $\mu$ mole ATP with PMS as cofactor) and were deprived of noncyclic phosphorylation activity. Maximum activity in the Hill reaction in the case of Scenedesmus obliquus was observed by Berzbon and Bishop (1973): the chloroplasts from 5-day algae showed in optimal conditions an activity of about 200 umoles DCPIP. $\mathrm{mg}^{-1} \mathrm{chl} / \mathrm{h}^{-1}$. With ageing of the algae this activity decreased to about $4 / 10$ of the initial value.

The aim of the present. study was the investigation of the influence of some herbicides on the growth of algae and on the Hill reaction catalysed by chloroplasts isolated from these algae. Comparison of these data led to certain conclusions as to the mechanism of action of the herbicides on the investigated algae.

\section{MATERIAL AND METHODS}

The alga Scenedesmus quadricauda was cultured on Uspeński medium of the following composition: $\mathrm{Ca}\left(\mathrm{NO}_{3}\right)_{2} \cdot 4 \mathrm{H}_{2} \mathrm{O}-0.207 ; \mathrm{KNO}_{3}-0.025$; $\mathrm{KH}_{2} \mathrm{PO}_{4}-0.025 ; \quad \mathrm{MgSO}_{4} \cdot 7 \mathrm{H}_{2} \mathrm{O}-0.050 ; \mathrm{K}_{2} \mathrm{CO}_{3}-0.0348 ; \mathrm{Fe}_{2}\left(\mathrm{SO}_{4}\right)_{3} \cdot 4 \mathrm{H}_{2} \mathrm{O}-$ 
-0.0017 . (g. per liter of medium). To 1 1. of medium $1 \mathrm{ml}$ of $\mathrm{A}-\mathrm{Z}$ Hoagland's microelements of the following composition was added (g per liter of solution): $\mathrm{H}_{3} \mathrm{BO}_{3}-0.61 ; \mathrm{AlCl}_{3}-0.78 ; \mathrm{LiCl}-0.025 ; \mathrm{KBr}-0.025$; $\mathrm{SnCl}_{2} \cdot 2 \mathrm{H}_{2} \mathrm{O}-0.025 ; \mathrm{CuSO}_{4} \cdot 5 \mathrm{H}_{2} \mathrm{O}-0.055 ; \mathrm{ZnSO}_{4} \cdot 7 \mathrm{H}_{2} \mathrm{O}-0.055 ; \mathrm{Co}\left(\mathrm{NO}_{3}\right)_{2}$. . $6 \mathrm{H}_{2} \mathrm{O}-0.055 ; \mathrm{MnCl}_{2} \cdot 4 \mathrm{H}_{2} \mathrm{O}-0.319 ; \mathrm{NiSO}_{4} \cdot 6 \mathrm{H}_{2} \mathrm{O}-0.055 ; \mathrm{H}_{2} \mathrm{MoO}_{4} \cdot \mathrm{H}_{2} \mathrm{O}-$ $-0.055 ; \mathrm{H}_{2} \mathrm{O}$ bidistilled-1000. Into a $300-\mathrm{ml}$ Erlenmeyer flask $100 \mathrm{ml}$ of medium was introduced, inoculum was added. The batch culture method was applied under constant illumination with fluorescent tubes. Light intensity was $4000-5000$ lux, temperature $24 \pm 2^{\circ} \mathrm{C}$. Under these conditions a good increment of dry weight of algae was obtained amounting to 3.4 and $11.7 \mathrm{mg} / 50 \mathrm{ml}$ culture on the 7 th and 10 th day, respectively.

\section{$\mathrm{Tab} 1 \mathrm{e} 1$}

Pure active components content in technical herbicide preparations

\begin{tabular}{l|c|c}
\hline \multicolumn{1}{c|}{ Herbicide } & $\begin{array}{c}\text { Pure active } \\
\text { component content, } \\
\%\end{array}$ & $\begin{array}{c}\text { Method of pure compound } \\
\text { determination (literature) }\end{array}$ \\
\hline 2,4-D & 80 & CIPAC 1970a \\
Gramoxone & 22 & CIPAC 1970b \\
Afalon & 44 & $*$ \\
Kresamone & 47 & CIPAC 1970a \\
Simazine & 51 & Zweig 1964a \\
CIPC & 21 & $* *$ \\
\hline
\end{tabular}

* One gram of technical preparation was extracted in the cold with methanol $2 \times 100 \mathrm{ml}$ (Into the 3rd portion of methanol only trace amounts of afalon are extracted). The combined extracts were diluted with methanol 500-fold and extinction was determined in the $250 \mathrm{~nm}$ band. From the comparison with extinction of the standard solution $\mathrm{E}_{250}^{\mathrm{g} / 1 \mathrm{ml}}=0.1025$ the pure compound content was calculated.

* For determination of the pure component content Zweig's (1964b) and CIPAC (1970d) methods were applied.

The results obtained were underrated considerably (below $12 \%$ ) probably owing to high contamination of the technical preparation with decomposition product. As the result of fractionating distillation under reduced pressure a fraction with b.p. $143^{\circ} \mathrm{C} / 4 \mathrm{~mm} \mathrm{Hg}$, refraction index $\mathrm{n}_{\mathrm{D}}^{2 \mathrm{G}}=1.5398$ was obtained corresponding by its parameters to the pure iosopropyl ester of chlorocarbanilic acid (Mielnikov, Baskakov, Bokariev, 1956). This fraction constituted 21 per cent of the technical preparation.

Herbicides representing various groups both as regards chemical structure and mechanism of action were selected for the tests. Solutions of technical preparations were used. Table 1 shows the pure active component content in each of the preparations.

The number of cells was determined in a Fuchs-Rosenthal chamber. Before counting the algae were killed by addition of 5 drops of an ethyl alcohol-formalin mixture ( 1 part $40 \%$ formalin to 3 parts of alcohol) to each flask. 
The packed cells volume (PCV) was determined according to Pratt and Bishop (1968): from $20 \mathrm{ml}$ of culture the algae were centrifuged off ( $5 \mathrm{~min}$ at $4000 \mathrm{~g}$ ), the supernatant was decanted and the sediment suspended in $0.06 \mathrm{~N} \mathrm{HCl}$ and made up to a total volume of $0.4 \mathrm{ml}$. The whole was mixed, poured into a cytocrit capillary and centrifuged for $5 \mathrm{~min}$ at $1000 \mathrm{~g}$. PCV was calculated from the formula PCV $=0.02 \mathrm{X}$, where $\mathrm{X}-$ reading in the cytocrit capillary (expressed in $\mu \mathrm{l}$ of PCV per $1 \mathrm{ml}$ culture).

Chlorophyll content in chloroplasts was determined by the method of Arn on (1949): $0.05 \mathrm{ml}$ of chloroplast suspension was made up to $10 \mathrm{ml}$ with an acetone-water mixture $(80: 20 \mathrm{v} / \mathrm{v})$. The whole was mixed, left to stand for $10 \mathrm{~min}$ and centrifuged for $5 \mathrm{~min}$ at $20000 \mathrm{~g}$. Extinction was measured in the supernatant in the $652 \mathrm{~nm}$ band $(1 \mathrm{~cm}$ cell). Chlorophyll content was calculated from the formula

$\mathrm{mg} \mathrm{chl} / \mathrm{ml}$ of initial suspension $=5.8 \cdot \mathrm{E}_{652}$

Chloroplasts were prepared out from 10-12-day algae after Pratt and Bishop (1968). For homogenization, beside a bead type Braun homogenizer, the method of $\mathrm{Semenenko}$ and $\mathrm{Kasatkina} \mathrm{(1972)}$ was also applied consisting in the use of a Unipan type 302 homogenizer with a homogenizing loop and $\varnothing=0.38 \mathrm{~mm}$ beads.

Electron transport was recorded by means of a DCPIP acceptor: DCPIP sodium salt was dissolved in phosphate buffer of required $\mathrm{pH}$ containing $0.06 \mathrm{M} \mathrm{KCl}$ and $0.2 \mathrm{M}$ sorbitol. DCPIP concentration was about $1.10^{-4} \mathrm{M}$, extinction in the $610 \mathrm{~nm}$ band was $\mathrm{E}_{610}=1.5-2.0$. To $3 \mathrm{ml}$ of this solution a chloroplast suspension containing $0.025-0.1 \mathrm{mg} \mathrm{chl}$ was added and the whole was made up to $6 \mathrm{ml}$. The sample obtained was divided into two $3-\mathrm{ml}$ parts. To one solid sodium dithionite was added up to complete reduction of DCPIP (blank). The sample for measurement was compared with the blank in the $610 \mathrm{~nm}$ band, illuminated for $2 \mathrm{~min}$ and measured once more. Illumination and extinction measurements were continued up to an overall time of $6-8 \mathrm{~min}$. Then the initial velocity of extinction changes caused by DCPIP photoreduction $\left(\Delta \mathrm{E}_{610} / \mathrm{min}\right)$ was plotted graphically. Activity was calculated from the result obtained:

$$
\mathrm{A}\left(\mu \text { mole red. DCPIP } / \mathrm{mg}^{-1} \mathrm{chl} . / \mathrm{h}^{-1}\right)=0.0563 \cdot \Delta \mathrm{E}_{610} \cdot 60 \frac{1000}{\mu \mathrm{g} \mathrm{chl} / \mathrm{ml}}
$$

taking advantage of the extinction coefficient ( $\mu$ mole red. DCPIP $\cdot \mathrm{ml}^{-1}=$ $\left.=0.0563 . \Delta \mathrm{E}_{610}\right)$ given by $\mathrm{Pratt}$ and $\mathrm{Bishop}(1968)$. The samples were illuminated with a halogen $600 \mathrm{~W} / 220 \mathrm{~V}$ lamp through a water filter and a suitable colour filter. Radiation intensity was measured with a Radiometer 65 apparatus (YSI, U. S. A.). 


\section{RESULTS}

\section{Influence of herbicides on growth of algae}

In this experimental combination the herbicides were introducted in appropriate concentrations into the medium on which the algae were cultured. After 14 days the dry weight, number of cells, number of deformed cells and PCV were determined. The experiments were replicated three times. Table 2 shows the results of determinations; the mean error in dry weight determination did not exceed \pm 0.4 , that of cell number \pm 16 , and that of $\mathrm{PCV} \pm 0.1$.

Table 2

Characteristic of algae culture on media containing herbicides

\begin{tabular}{|c|c|c|c|c|c|}
\hline \multirow[b]{2}{*}{ Herbicide } & \multirow{2}{*}{$\begin{array}{c}\text { Herbicide } \\
\text { concentration } \\
\text { (tęchn. prep.) } \\
\text { mg/1 liter medium }\end{array}$} & \multirow[b]{2}{*}{$\begin{array}{c}\text { Dry weight of algae, } \\
\mathrm{mg} / 50 \mathrm{ml}\end{array}$} & \multicolumn{2}{|c|}{ Cell number } & \multirow[b]{2}{*}{ PCV } \\
\hline & & & total & $\begin{array}{l}\text { no. of } \\
\text { deformed } \\
\text { cells }\end{array}$ & \\
\hline \multirow{4}{*}{$\begin{array}{l}\text { Control } \\
2,4-\mathrm{D}\end{array}$} & 0.0 & 10.0 & 680 & - & 4.5 \\
\hline & 5.0 & 8.8 & 672 & 34 & 4.5 \\
\hline & 50.0 & 10.6 & 812 & 69 & 6.5 \\
\hline & 500.0 & 15.1 & 1050 & 78 & 4.5 \\
\hline \multirow[t]{3}{*}{ Gramoxone } & 0.05 & 7.7 & 654 & 49 & 4.0 \\
\hline & 0.5 & 7.4 & 523 & 98 & 3.0 \\
\hline & 5.0 & 2.5 & 367 & 102 & 1.0 \\
\hline \multirow[t]{2}{*}{ Afalon } & 0.05 & 7.8 & 532 & single & 3.5 \\
\hline & 0.5 & 3.6 & 325 &, & 2.0 \\
\hline \multirow[t]{3}{*}{ Kresamone } & 0.05 & 9.7 & 712 & 26 & 3.5 \\
\hline & 0.5 & 7.6 & 640 & 32 & 3.0 \\
\hline & 5.0 & 7.0 & 556 & 68 & 4.5 \\
\hline \multirow[t]{3}{*}{ CIPC } & 0.05 & 9.9 & 789 & 38 & 7.0 \\
\hline & 0.5 & 9.4 & 751 & 28 & 6.0 \\
\hline & 5.0 & 7.1 & 700 & 132 & 5.0 \\
\hline \multirow[t]{2}{*}{ Simazine } & 0.05 & 8.8 & 632 & 140 & 4.0 \\
\hline & 0.5 & 6.0 & 426 & 138 & 3.5 \\
\hline
\end{tabular}

Comparison of the action of various herbicides leads to the conclusion that most strongly toxic is Afalon which reduces dry weight cell number as well as PCV. Less toxic proved Simazine and Gramoxone. The inhibitory action of Kresamone and CIPC is weak and 2,4-D, particularly in lower concentration, has a stimulating effect on the growth of algae.

Noteworthy, however, is the fact that Afalon acting strongly on growth does not cause any deformation of the algae, whereas in the presence of Simazine, CIPC and Gramoxone deformed cells are numerous.

Comparison of dry weight and PCV when converted to values per one cell is also interesting. These values expressed in relative units are shown 
Table 3

Effect of herbicides on dry weight and PCV of a single cell

\begin{tabular}{|c|c|c|c|c|}
\hline Herbicide & $\begin{array}{c}\text { Herbicide } \\
\text { concentration } \\
\text { (techn. prep.) } \\
\text { mg/1 litre medium }\end{array}$ & Dry weight & no. of cells & Remarks \\
\hline Control & 0.0 & $1.47 \cdot 10^{-2}$ & $6.6 \cdot 10^{-3}$ & \\
\hline 2,4-D & $\begin{array}{c}5.0 \\
150.0 \\
500.0\end{array}$ & $\begin{array}{l}1.31 \\
1.31 \\
1.44\end{array}$ & $\begin{array}{l}6.7 \\
8.0 \\
4.3\end{array}$ & \\
\hline Gramoxone & $\begin{array}{l}0.05 \\
0.5 \\
15.0\end{array}$ & $\begin{array}{l}1.18 \\
1.42 \\
0.68\end{array}$ & $\begin{array}{l}6.1 \\
5.7 \\
2.7\end{array}$ & Very small \\
\hline Afalon & $\begin{array}{l}0.05 \\
0.5\end{array}$ & $\begin{array}{l}1.47 \\
1.11\end{array}$ & $\begin{array}{l}6.6 \\
6.3\end{array}$ & \\
\hline Kresamone & $\begin{array}{l}0.05 \\
0.5 \\
5.0\end{array}$ & $\begin{array}{l}1.37 \\
1.19 \\
1.25\end{array}$ & $\begin{array}{l}4.9 \\
4.7 \\
8.1\end{array}$ & \\
\hline CIPC & $\begin{array}{l}5.0 \\
0.05 \\
0.5 \\
5.0\end{array}$ & $\begin{array}{l}1.25 \\
1.25 \\
1.25 \\
1.01\end{array}$ & $\begin{array}{l}8.1 \\
8.9 \\
8.0 \\
7.2\end{array}$ & $\begin{array}{c}\text { Swollen, light } \\
\qquad, \\
,,\end{array}$ \\
\hline Simazine & $\begin{array}{l}0.05 \\
0.5\end{array}$ & $\begin{array}{l}1.40 \\
1.60\end{array}$ & $\begin{array}{l}6.3 \\
8.2\end{array}$ & large. heavy \\
\hline
\end{tabular}

in Table 3. It results from comparison of these data and those from the preceding table that Afalon greatly reduces the number of cells without changing their weight and volume. Kresamone and CIPC prompt the formation of swollen and light cells whereas Simazine favours development of large and heavy ones. In the presence of Gramoxone the cells formed are very small. These conclusions confirm the microscopic observations that in treatment with Gramoxone small bead-like cells arise in long chains. In the presence of Kresamone and CIPC the cells are much larger than normal, round and frequently deprived of the cytoplasmic content. Similar large round cells, but well filled, form in treatment with Simazine.

\section{Influence of herbicides on Hill's reaction with CDPIP as acceptor}

In preliminary experiments optimal conditions of Hill reaction measurement on chloroplasts isolated from algae were established.

It was found, when investigating the influence of $\mathrm{pH}$ on Hill's reaction (under illumination of ca. $1.7 \times 10^{6} \mathrm{erg} / \mathrm{cm}^{-2}$, through a wide-band OG3 Schott, Jena filter), that the optimum $\mathrm{pH}$ range is wide, lying between 7.0 and 7.5 ; in this $\mathrm{pH}$ interval chloroplast activity shows values of 36.8 $27.7 \mu$ moles of reduced DCPIP per $1 \mathrm{mg}$ chlorophyll/h.

If we change the wavelength of the illuminating radiation (with constant radiation intensity equal to $8.2 \times 10^{5} \mathrm{erg} / \mathrm{cm}^{-2}$ and constant $\mathrm{pH}$ of 
the solution equal to 7.0 ) radiation with $\lambda$ above $670 \mathrm{~nm}$ is inactive as regards Hill's reaction (filter RG5, Schott, Jena; activity A =6.2). For RG1 $(\lambda>620 \mathrm{~nm})$, OG3 $(\lambda>560 \mathrm{~nm})$ and BG12 (transmittance band $350-470$ $\mathrm{nm}$ ) filters the activities were within the limits $37.4-34.4$.

Investigations of the influence of radiation intensity on Hill's reaction demonstrated that under the measuring conditions a state of saturation is reached at an intensity of about $1 \times 10^{6} \mathrm{erg} \cdot \mathrm{cm}^{-2}$. In preliminary investigations the dependence of chloroplast activity in Hill's reaction or the age of the algae was verified. Investigation of the activity of chloroplasts prepared out from algae cultured for $8-20$ days showed that this activity in chloroplasts from 8-11-day cultures remains at the same level. In view of the rather slow development of algae it was not possible to examine the activity in algae cultured for a shorter time. On the other hand, chloroplasts from 13-day algae show a marked decrease of activity (by ca. 20\%) and 18-20-day ones contain chloroplasts with a very low activity (of the order to $10 \%$ maximum).

The time of storage also affects the chloroplast activity. For $2-6 \mathrm{~h}$ after being prepared out the chloroplasts maintain a constant activity, but after $24 \mathrm{~h}$ at $2^{\circ} \mathrm{C}$ they lose about 50 per cent of it, and longer storage (above $72 \mathrm{~h}$ ) ended in complete desactivation of the preparation.

The above described experiments allowed to establish the optimal conditions for investigation of the effect of herbicides on Hill's reaction: the experiments were performed with chloroplasts within the period of $2-6 \mathrm{~h}$ after preparing out from 9-11-day algae. To the tested solution (see Methods) of $\mathrm{pH} 7.0$, herbicide of the desired concentration was introduced (converted to the active component of the technical product). The solution was illuminated with a halogen lamp through a water filter and an RG1 Schott, Jena filter. Radiation intensity was about $1.7 \times 10^{6} \mathrm{erg} / \mathrm{cm}^{-2}$.

The results obtained with various concentrations of Simazine CIPC, Afalon and Gramoxone are given in table 4. The two remaining herbici-

Table 4

Effect of herbicides on activity of chloroplasts from algae in Hill's reaction

\begin{tabular}{|c|c|c|c|c|c|c|c|}
\hline \multicolumn{2}{|c|}{ Simazine } & \multicolumn{2}{|c|}{ CIPC } & \multicolumn{2}{|c|}{ Afalon } & \multicolumn{2}{|c|}{ Gramoxone } \\
\hline $\begin{array}{c}\text { concentration } \\
\mathrm{M}\end{array}$ & $\begin{array}{c}\text { activity } \\
\%\end{array}$ & $\begin{array}{c}\text { concentration } \\
\mathrm{M}\end{array}$ & $\begin{array}{c}\text { activity } \\
\%\end{array}$ & $\begin{array}{c}\text { concentration } \\
\mathrm{M}\end{array}$ & $\begin{array}{c}\text { activity } \\
\%\end{array}$ & $\begin{array}{c}\text { concen- } \\
\text { tration } \\
M\end{array}$ & $\begin{array}{c}\text { activity } \\
\%\end{array}$ \\
\hline 0.0 & 100 & 0.0 & 100 & 0.0 & 100 & 0.0 & 100 \\
\hline $1.2 \cdot 10^{-8}$ & 85 & $2 \cdot 10^{-8}$ & 100 & $1.5 \cdot 10^{-7}$ & 78 & $2 \cdot 10^{-5}$ & 92 \\
\hline $1.2 \cdot 10^{-7}$ & 70 & $2 \cdot 10^{-7}$ & 94 & $1.5 \cdot 10^{-6}$ & 39 & $4 \cdot 10^{-5}$ & 85 \\
\hline $1.2 \cdot 10^{-6}$ & 58 & $2 \cdot 10^{-6}$ & 88 & $1.5 \cdot 10^{-5}$ & 9 & $8 \cdot 10^{-5}$ & 67 \\
\hline $1.2 \cdot 10^{-5}$ & 41 & $2 \cdot 10^{-5}$ & 88 & $1,5 \cdot 10^{-4}$ & 0 & & \\
\hline
\end{tabular}


des not included in this table $\left(2,4-\mathrm{D}\right.$ in concentrations up to $1 \times 10^{-3} \mathrm{M}$ and Kresamone in concentrations up to $1 \times 10^{-4} \mathrm{M}$ ) had no significant inhibitory or stimulating effect on Hill's reaction.

\section{DISCUSSION}

The aim of the study was to compare the influence of herbicides on the growth of algae and on the Hill reaction and to obtain some information on the site of action of the tested herbicides. Unequivocal characterization of this kind is only possible in the case Afalon. It results from table 4 that 50 per cent of electron transport inhibition is observed at a concentration of $8 \times 10^{-7} \mathrm{M}$ of Afalon. It may be concluded also from table 2 and 3 that Afalon inhibits growth of algae in 50 per cent (as measured by cell number and their dry weight) at a concentration of $1 \times 10^{-6}$ M without eliciting the appearance of deformed cells. This parallelism seems to indicate that the only site of action of Afalon on algae is the chain of electron transport in the neighbourhood of PS II.

A weaker inhibitory influence than that of Afalon, but still rather strong is exerted on Hill's reaction by the herbicides Simazine, CIPC and Gramoxone. The influence of Gramoxone on Hill's reaction with the DCPIP acceptor confirms indirectly the observations of Gromet and A vro n (1963) that the PSI system has its part in DCPIP photoreduction. The inhibition of the PSI function by Gramoxone would explain the slight inhibition of DCPIP photoreduction. At the same time, however, Gramoxone, particularly in higher concentration $(5 \mathrm{mg}$ of the crude preparation per 1 litre of medium, corresponding to a $4.3 \times 10^{-6} \mathrm{M}$ concentration) causes a strong inhibition of growth of the algae, reduction of the celi size and considerable morphological changes. These effects may probably be explained by the ability of Gramoxone to reoxidation of NADPH (this leading to inhibition of synthesis of carbohydrates and all other compounds required by the organism). and also by the accumulation of phytotoxic products of Gramoxone reduction (B l a ck and Meyers, 1966).

Simazine inhibits rather strongly Hill's reaction in isolated chloroplasts 50 per cent inhibition is observed at a concentration of about $6 \times 10^{-6} \mathrm{M}$. The influence of Simazine on the growth of algae is similar; in a concentration of $1.2 \times 10^{-6} \mathrm{M} / 0.5 \mathrm{mg}$ of technical product per 1 litre of medium, the number of cells is reduced by about 60 per cent as compared with the control. This herbicide at the same time causes marked morphological changes, causing the formation of numerous large and heavy cells. This points to some side effect of Simazine or of its decomposition products on. metabolism and cell division processes in algae.

As regards the 3 remaining herbicides, CIPC, Kresamone and 2,4-D, their physiological effect is certainly not connected with their action on 
electron transport in the neighbourhood of the PS II system. Only one of these substances, CIPC, slightly inhibits Hill's reaction, whereas both CIPC and 2,4-D enhance cell production. This action in the case of CIPC is inversely proportional to the concentration within the range $5 \times 10^{-8}$ to $5 \times 10^{-6} \mathrm{M}$. At the same time, together with the increase in CIPC concentration, the number of degenerated, swollen cells deprived of cytoplasmic contents increases, indicating the noxious influence of CIPC and its decomposition products on cell metabolism. This noxious effect is not observed in the case of 2,4-D: a rise of concentration of this herbicide within the limits $1.8 \times 10^{-5}$ to $1.8 \times 10^{-3} \mathrm{M}$ produces a gradual increase in the number of cells (up to $150 \%$ in relation to the control). It should be stressed that the cells formed are normal, what shows an exclusively.stimulating effect of 2,4-D on the growth of algae. Thus there is an essential difference between the action of 2,4-D on the alga Scenedesmus quadricauda and on higher plants.

The present study was performed under a grant from the research program "Environment protection" of the Wrockaw Technical University under contract no. $90 / \mathrm{JB} / 73$.

\section{REFERENCES}

A rnon D. I., 1949. Plant Physiol. 24 (1).

Berzborn R. J., Bishop N. J., 1973. Biochim. Biophys. Acta 292 (700).

Bla ck C. C., M eyers L., 1966. Weeds 14: 331.

CIPAC, ed. G. R. R a w, 1970, Handbook vol. I, 241.

CIPAC, ed. G. R. R a w, 1970, Handbook vol. I, 547.

CIPAC, ed. G. R. R a w, 1970, Handbook vol. I, 348.

CIPAC, ed. G. R. R a w, 1970, Handbook vol. I, 223.

Gr a h a m D., S mili e R. M., 1971. in Methods in Enzymology, Part A, Acad. Press, 23: 240 .

Gromet-Elhanan Z., Avron M., 1963. Biochem. Biophys. Res. Commun. 10: 215.

H a milt o n R. H., M or el a n d D. E., 1962. Science 135: 373.

H e n d erson J. H., M iller J. H., Des s e D. C., 1954. Science 120: 710.

I z a w a S., G o o d N. E., 1965. Biochim. Biophys. Acta 102: 20.

K e a r n e y P. C., K a u $\mathrm{m}$ a $\mathrm{n}$ D. D., 1971. Degradation of herbicides, thum. ros.

Lock h art J. A., We in tr a u b R. L., 1957. Amer. J. Bot. 44: 424.

Masztakow S., Diejewa W., Wołyniec A., 1971. Działanie herbicydów na rośliny uprawne, tłum. polskie PWRiL, Warszawa.

Mielnikow N. N., Baskakow Ju. A., Bokariew K. S., 1965. Chemia środków chwastobójczych i roślinnych hormonów wzrostowych, tłum. polskie PWT, Warszawa.

M o r e l a n d D. E., 1967. Ann. Rev. Plant Physiol. 18: 365.

Pr a t t L. H., B is h o p N. J., 1968. Biochim Biophys. Acta 153: 664.

Semenenko W. E., Ka s a t k in a T. I., 1972. Plant Physiol. 19: 169, Moskow. Tetik K., 1969. Ann. Report of the Laboratory of Algology, Trebon, str. 90. 
Z w e ig G., 1964. Pesticides, plant growth regulators and food additives, Acad. Pres;, 4: 216 .

Z we ig G. 1964. Pesticides, plant growth regulators and food additives, Acad. Press. 4: 55 .

Authors' address:

Doc. dr Wacław Hendrich et al.

Institute of Biochemistry,

Wrockaw University,

Tamka 2; 50-137 Wrocław; Poland

Wplyw herbicydów na fotosyntetyczny transport elektronów i na wzrost glonów Scenedesmus quadricauda

\author{
Streszczenie
}

Badano działanie herbicydów: 2,4-D, gramoksonu, afalonu, krezamonu, CIPC i simazinu na wzrost glonów Scenedesmus quadricauda i na reakcję Hilla. Wzrost glonów na pożywce Uspeńskiego, zawierającej różne stężenia herbicydów kontrolowano pomiarami suchej masy i objętości upakowanych komórek oraz liczby komórek normalnych i zniekształconych. Reakcję Hilla z akceptorem DCPIP prowadzono w obecności różnych stężeń herbicydów i chloroplastów izolowanych z glonów hodowanych na pożywce bez herbicydów.

Stwierdzono, że 2,4-D w stężeniach $\mathrm{c}=5-500 \mathrm{mg} / 1$ stymuluje wzrost glonów, nie wpływając na reakcję Hilla. Krezamon $(c=0,05-0,5 \mathrm{mg} / 1)$ słabo hamuje wzrost glonów, również nie wpływając na reakcję Hilla. CIPC w tym samym zakresie stężeń słabo stymuluje wzrost glonów, równocześnie hamując reakcję Hilla. Pozostałe trzy herbicydy silnie hamują zarówno wzrost glonów jak i reakcję Hilla. Afalon w stężeniu $10^{-6} \mathrm{M}$ hamuje w tym samym stopniu $(50 \%)$ reakcję Hilla i rozwój glonów, nie powodując wystẹpowania komórek zniekształconych. Ta równoległość działania pozwala przypuszczać, że jedynym miejscem działania afalonu na glony jest łańcuch transportu elektronów w sąsiedztwie PS II.

Simazin i gramokson hamują w niejednakowym stopniu wzrost glonów i reakcję Hilla. Równocześnie te dwa herbicydy oraz CIPC powodują występowanie licznych komórek zniekształconych; pozwala to przypuszczać, że hebicydy te wywierają bezpośredni wpływ na metabolizm i mechanizm podziału komórkowego glonów. 